\title{
鉛フリー快削性銅合金“75.5Cu-3Si-0.1P-Zn”の 金属組織と耐脱亜鉛腐食性
}

\section{大石恵一郎田中真 次 後 藤 佳 行}

三宝伸銅工業株式会社開発センター

J. Japan Inst. Metals, Vol. 67, No. 5 (2003), pp. 219-225

(C) 2003 The Japan Institute of Metals

\section{Dezincification Corrosion Resistance and Microstructure of Lead-Free Free-Cutting Copper Alloy “75.5Cu-3Si-0.1P-Zn”,}

Keiichiro Oishi, Shinji Tanaka and Yoshiyuki Goto

Research and Development, Sambo Copper Alloy Co., Ltd., Sakai 590-0906

We have developed a free-cutting copper alloy " $75.5 \mathrm{Cu}-3 \mathrm{Si}-0.1 \mathrm{P}-\mathrm{Zn}$ " free of lead which is known to be harmful to the human body. The microstructure of this developed alloy consists of $\alpha, \kappa$ and $\gamma$ phases. The two hard $\kappa$ and $\gamma$ phases act as a source of stress at the time of cutting. As a result, the $75.5 \mathrm{Cu}-3 \mathrm{Si}-0.1 \mathrm{P}-\mathrm{Zn}$ alloy is obtained in finely segmented chips with low cutting resistance. Incidentally, for plumbing fixtures such as cocks, vessels, valves, and joints related to the daily intake of tap water, copper alloys containing 2 6 mass\% lead are used. A switch to a lead-free material in the water supply system is urgently required. At the same time, accidents due to dezincification corrosion associated with water quality are frequently encountered in Japan, and there is a strong demand for materials with excellent dezincification corrosion resistance. In this study, we investigated the microstructure and dezincification corrosion resistance of the developed alloy by the ISO 6509 test method.

Single-phase alloys of $\alpha, \kappa$ and $\gamma$ phases were prepared by laboratory methods and their dezincification corrosion was evaluated. The $\alpha$ phase and $\kappa$ phase each has excellent dezincification corrosion resistance and the $\gamma$ phase also has good dezincification corrosion resistance. Therefore, the developed alloy consisting of these phases is believed to have excellent dezincification corrosion resistance.

(Received November 18, 2002; Accepted March 5, 2003)

Keywords: dezincification corrosion resistance, lead-free, free-cutting, copper alloy, ISO 6509, water supply system, tap water, $\kappa$ phase, $\gamma$ phase

\section{1. 緒言}

わが国は過去においてカドミウム，水銀など重金属による 極めて悲惨な被害を経験した ${ }^{1)}$. 鉛は急性の毒性が少ないた めその危機意識は一般に低いが，鉛の人体への蓄積作用によ り神経障害, 消化器系の異常 2 , , 乳幼児の発達障害3)などを 引き起こすと報告されている. 鉛に関しても過去の教訓を生 かし，代替物質と技術がある限りは，世界に先立って順次鉛 フリー材料化を押し進めていくことが当然と考えられる.

近年環境污染問題で, はんたに含まれている鉛が大きく取 り上げられている4). 銅合金に抢いても材料の被削性を増す ために鉛が添加され，それに用いられる鉛は，はんだとして 使用される鉛の量にほぼ匹敵する ${ }^{5,6)}$. 鉛添加銅合金の中 で，鉛を 2〜6 mass\%添加した CAC406 (青銅鋳物), C3604 (快削黄銅) および C 3771 (鍛造用黄銅) は, 我々が毎日攝取 する水道水に係わる蛇口, 給水栓, 継手, バルブなどの器具 類の主材料として用いられている.これら器具類から溶出す る鉛によって, 源水より高い濃度の鉛が水道水を通して直接 人体に入ることを考えれば, 鉛添加銅合金に添加される鉛 は, はんだ含まれる鉛と同等またはそれ以上に重要な問題
と言える. 特に, 日本の水道水は一般に軟水と呼ばれ, 諸外 国に比べ脱亜鉛腐食や全面溶解腐食を起こさせ易い水質7-9) であるため, 鉛添加銅合金から腐食現象に伴って相当量の鉛 が水道水中に溶出していることが懸念される10,11).

1980 年代半ばから，鉛フリー快削性銅合金の開発が始め られ，公表されている開発合金のほとんどは鉛をビスマスに 置き換えたものである12).ところがビスマス添加銅合金 は, ビスマスの資源上 ${ }^{13)}$, 安全性 ${ }^{14,15)}$, 被削性 ${ }^{16)}$ の問題など があり，実用化が進んでいるとは言い難い。

我々は安全性が確認され, 資源上も問題のない元素 Si の 添加で，鉛を排除した $75.5 \mathrm{Cu}-3 \mathrm{Si}-0.1 \mathrm{P}-\mathrm{Zn}$ 鉛フリー快削性 銅合金を開発してきた ${ }^{17)}$.この合金は $\alpha$ 相と $\kappa$ 相抢よび少 量の $\gamma$ 相からなる金属組織を示し, $\kappa$ 相, $\gamma$ 相の両硬質相が 切削時の応力集中源として作用し，せ九断角を大きくし，せ ん断ひずみを小さくさせることにより，優れた切屑の分断性 と低い切削抵抗を示す17). また用途上熱間押出性，熱間鍛 造性，鋳造性と共に耐脱亜鉛腐食性が必須の特性であること をあらかじめ十分考慮に入れた合金である。銅と亜鉛をべー スとする合金に抢いて，3 mass\% Si の添加は脱亜鉛腐食感 受性を高める亜鉛含有量 ${ }^{18-20)}$ の低減と $\beta$ 相の残留を工業量 産レベルで阻止できると推測され，さらに $\alpha$ 相の脱亜鉛腐 
食を抑制する $\mathrm{P}^{21,22)}$ を添加することにより，安定した耐脱 亜鉛腐食性が得られるものと考えられる。

本研究では $75.5 \mathrm{Cu}-3 \mathrm{Si}-0.1 \mathrm{P}-\mathrm{Zn}$ 合金の脱亜鉛腐食性を, ISO 6509 の脱亜鉛腐食試験方法 ${ }^{23)}$ にしたがって評価した. 合金構成相である $\alpha$ 相, $\kappa$ 相および $\gamma$ 相各単相合金試料と $\mathrm{Cu}-\mathrm{Si}-\mathrm{Zn}$ 合金の $\beta$ 単相合金試料を実験室的に作り，それら 単相合金試料の脱亜鉛腐食性を $\mathrm{Cu}-\mathrm{Zn}$ 合金との比較で評価 した.

\section{2. 実 験 方 法}

鉊フリー快削性銅合金 $75.5 \mathrm{Cu}-3 \mathrm{Si}-0.1 \mathrm{P}-\mathrm{Zn}$ (三宝伸銅工 業侏製，不純物として 0.03 mass $\% \mathrm{~Pb}$ を含む，以下本合金 という) 抢よび 3.1 mass $\% \mathrm{~Pb}$ を含有した $58.5 \mathrm{Cu}-3.1 \mathrm{~Pb}$ $0.2 \mathrm{Fe}-0.2 \mathrm{Sn}-\mathrm{Zn}$ の $\mathrm{C} 3604$ (快削黄銅棒) を供試材として用い た. 本合金は直接押出により製造した直径 $38 \mathrm{~mm} の$ 棒材, それを素材として熱間鍛造した鍛造品および砂型鋳物を用い た.なお，押出材，熱間鍛造品，鋳物ともに成形後一切の熱 処理は加えていない。これら供試材をISO 6509 に基づいた 脱亜鉛試験方法により，脱亜鉛腐食性を評価した，同時に試 験溶液中の $\mathrm{Pb}$ 濃度を測定し, $\mathrm{Pb}$ の溶出量を求めた. この 脱亜鉛腐食試験は $348 \mathrm{~K} \pm 5 \mathrm{~K}$ に加温した $\mathrm{CuCl}_{2}$ 水溶液中に 暴露面積 $100 \mathrm{~mm}^{2}$ の供試材を $86.4 \mathrm{ks}$ 浸漬した後，断面を 観察し，脱亜鉛腐食の評価を行う試験方法である。また， $a$ 相， $\kappa$ 相抢よび $\gamma$ 相を EPMA で定量分析し，その結果から 安定して単相合金試料が得られる組成を検討し, 電気銅, 電 気亜鉛， Cu-10 mass $\% \mathrm{Si}$ および Cu-10 mass \% P を所定の組 成に秤量後, アルゴン䨌囲気中で溶解によりビレット（直径 $35 \mathrm{~mm} \times$ 高さ $150 \mathrm{~mm}$ )を作製した。比較材として $\mathrm{Cu}-\mathrm{Si}-\mathrm{Zn}$ 合金の $\beta$ 単相合金試料, $\mathrm{Cu}-\mathrm{Zn}$ 合金の $\alpha$ 相， $\beta$ 相および $\gamma$ 相の各単相合金試料，本合金および C3604 のベースとなる $60 \mathrm{Cu}-40 \mathrm{Zn}$ 合金試料を作製した。なお，これらの試料には $\mathrm{P}$ を各々約 0.07 mass\%添加した. 試料はいずれも $873 \mathrm{~K}$ で $7.2 \mathrm{ks}$ 保持後, 水冷し, 各試料が単相あるいは所定の構成相 であることを確認後，脱亜鉛腐食評価を行った。

\section{3. 実験結果および考察}

\section{1 実用合金の耐脱亜鉛腐食性と鉛の溶出}

Fig. 1 に本合金の棒材，鍛造品，鋳物および比較材 C3604 の棒材の脱亜鉛腐食試験結果を示す. Fig. 1(d)の C3604 は, $1000 \mu \mathrm{m}$ を超える著しい脱亜鉛腐食を起こしているが，本 合金 (Fig. 1(a), Fig. 1(b), Fig. 1(c))の脱亜鉛腐食の深さは 熱履歴の異なるいずれの試料においても，最大で $10 \mu \mathrm{m}$ 未 満の脱亜鉛腐食深さである。

Table 1 に各試料の平均脱亜鉛腐食深さ, 平均全面溶解深 さおよび暴露面積 $100 \mathrm{~mm}^{2}$ の試料から試験溶液中に溶出し た $\mathrm{Pb}$ の分析結果を示す. C3604の場合，脱亜鉛腐食層内に 存在していた $\mathrm{Pb}$ は，平均腐食深さから算出すると約 28.5 $\mathrm{mg}$ になる。試験液中に溶出した $\mathrm{Pb}$ は $27.2 \mathrm{mg}$ であり, 計 算值の約 $95 \%$ に相当することから，未固溶 $\mathrm{Pb}$ 粒子の多く は，Zn と共に溶出していることを示している，一方，本合
金の場合，試験液中に溶出した $\mathrm{Pb}$ の量は $0.05 \mathrm{mg}$ 未満であ るが，同様に計算值から推測すると約 $0.01 \mathrm{mg}$ になり，脱 亜鉛腐食感受性の高い C3604 と比べ，材料中の $\mathrm{Pb}$ の含有 比率以上に $\mathrm{Pb}$ の溶出量は少ない.

Fig. 2 に, 水道関連器具部品として約 7 ケ月間実際に使用 された C3604 切削加工品の断面組成像と $\mathrm{Pb}$ の面分析結果 を示す。使用環境は $\mathrm{pH}$ が低く, 遊離炭酸イオン濃度が高い 脱亜鉛腐食を起こさせ易い水質である ${ }^{7-9)}$ ．この部品の脱亜 鉛腐食深さは 1 年に換算すると約 $400 \mu \mathrm{m}$ になる. また脱亜 鉛腐食層に存在する $\mathrm{Pb}$ は，原形を留めておらず，健全部に 比べ $\mathrm{Pb}$ の相対強度で約 $20 \%$ に低下している. 単純な仮定 であるが, 飲用に供する器具がすべて C3604であり, その 接水面積が $3 \times 10^{-2} \mathrm{~m}^{2}$ で，脱亜鉛腐食層内にある $\mathrm{Pb}$ の $80 \%$ が溶出するとすれば, 計算上年間約 $2.5 \mathrm{~g}$ の $\mathrm{Pb}$ が水道 水中に溶け込むことになる。この場合, 使用水量によるが WHO で定められた $\mathrm{Pb}$ の水質基準值 ${ }^{24)} 0.01 \mathrm{mg} / 1$ を大幅に 越える可能性がある. 本合金の比較データはないが，脱亜鉛 腐食試験の結果から不純物として $\mathrm{Pb}$ を 0.03 mass \% 含有す る本合金の実使用上の $\mathrm{Pb}$ 溶出量は，C3604 に比べ $1 / 1000$ 以下と予測される。

\section{2 金属組織}

Fig. 1 から本合金の棒材, 鍛造品, 鋳物の金属組織はいず れも母地の $\alpha$ 相, $\kappa$ 相と一部 $\gamma$ 相からなっている. 各相の形 状, 結晶粒の大きさおよび分布に差はあるが, 棒材, 鍛造 品, 鋳物の $\alpha, \kappa, \gamma$ 相の比率は, 各々 $70: 27: 3,75: 21: 4$, $75: 22: 3$ で大差はないと考えられる.

Fig. 3 に $673 \mathrm{~K}, 873 \mathrm{~K}$ および $973 \mathrm{~K}$ の $\mathrm{Cu}$ に富む領域で の $\mathrm{Cu}-\mathrm{Si}-\mathrm{Zn}$ 系 3 元状態図 ${ }^{25)}$ を示す. 本合金は熱間加工温度 である $973 \mathrm{~K}$ で $\alpha+\beta$ 組織を示し, $973 \mathrm{~K}$ から $873 \mathrm{~K}$ の間で, $\alpha+\beta \rightarrow \kappa$ の包析反応々 $\beta \rightarrow \alpha+\gamma$ の共析反応により $\kappa$ 相, $\gamma$ 相 が析出 ${ }^{25)}$ L, $\beta$ 相領域が急激に高 $\mathrm{Zn}$ 低 $\mathrm{Si}$ 側に移行する.こ れらの反応により, 実用本合金各材料の金属組織は, $873 \mathrm{~K}$ で $\beta$ 相のほとんどは消滅し， $\beta \rightarrow \alpha+\gamma$ の共析反応によって生 じる $\gamma$ 相が一部で残留するものの， $\alpha+\kappa$ を基本とする金属 組織を示すものと考えられる，一方，低温側の $783 \mathrm{~K}$ で $\kappa \rightarrow$ $\alpha+\mu$ の共析反応が生じるとされている25). 実用合金製造工 程での冷却速度は, 棒径, 肉厚, 形状, 大きさにより変化す るが約 $750 \mathrm{~K}$ で通常 $0.3 \mathrm{~K} / \mathrm{s}$ 以上であるため， $\mu$ 相の析出は

Table 1 ISO 6509 test results and the amount of lead leached into the solution from (a) $75.5 \mathrm{Cu}-3 \mathrm{Si}-0.1 \mathrm{P}-\mathrm{Zn}$ alloy bar, (b) $75.5 \mathrm{Cu}-3 \mathrm{Si}-0.1 \mathrm{P}-\mathrm{Zn}$ alloy forging, (c) $75.5 \mathrm{Cu}-3 \mathrm{Si}-0.1 \mathrm{P}-\mathrm{Zn}$ alloy casting, (d) C3604 bar.

\begin{tabular}{lccc}
\hline \multicolumn{1}{c}{ Alloys } & $\begin{array}{c}\text { Average gener- } \\
\text { al corrosion } \\
\text { depth }(\mu \mathrm{m})\end{array}$ & $\begin{array}{c}\text { Average } \\
\text { dezincification } \\
\text { depth }(\mu \mathrm{m})\end{array}$ & $\begin{array}{c}\text { Amount of } \mathrm{Pb} \\
\text { leached }(\mathrm{mg})\end{array}$ \\
\hline $\begin{array}{l}\text { (a) } 75.5 \mathrm{Cu}-3 \mathrm{Si}-0.1 \mathrm{P}-\mathrm{Zn} \\
\text { alloy bar }\end{array}$ & 50 & 0 & $<0.05$ \\
(b) $75.5 \mathrm{Cu}-3 \mathrm{Si}-0.1 \mathrm{P}-\mathrm{Zn}$ & 55 & 0 & $<0.05$ \\
alloy forging & 55 & 0 & $<0.05$ \\
(c) $75.5 \mathrm{Cu}-3 \mathrm{Si}-0.1 \mathrm{P}-\mathrm{Zn}$ & 0 & 1080 & 27.20 \\
\hline (d) C3604 bar & alloy casting & &
\end{tabular}

※ The exposed area of each specimen was $100 \mathrm{~mm}^{2}$. 

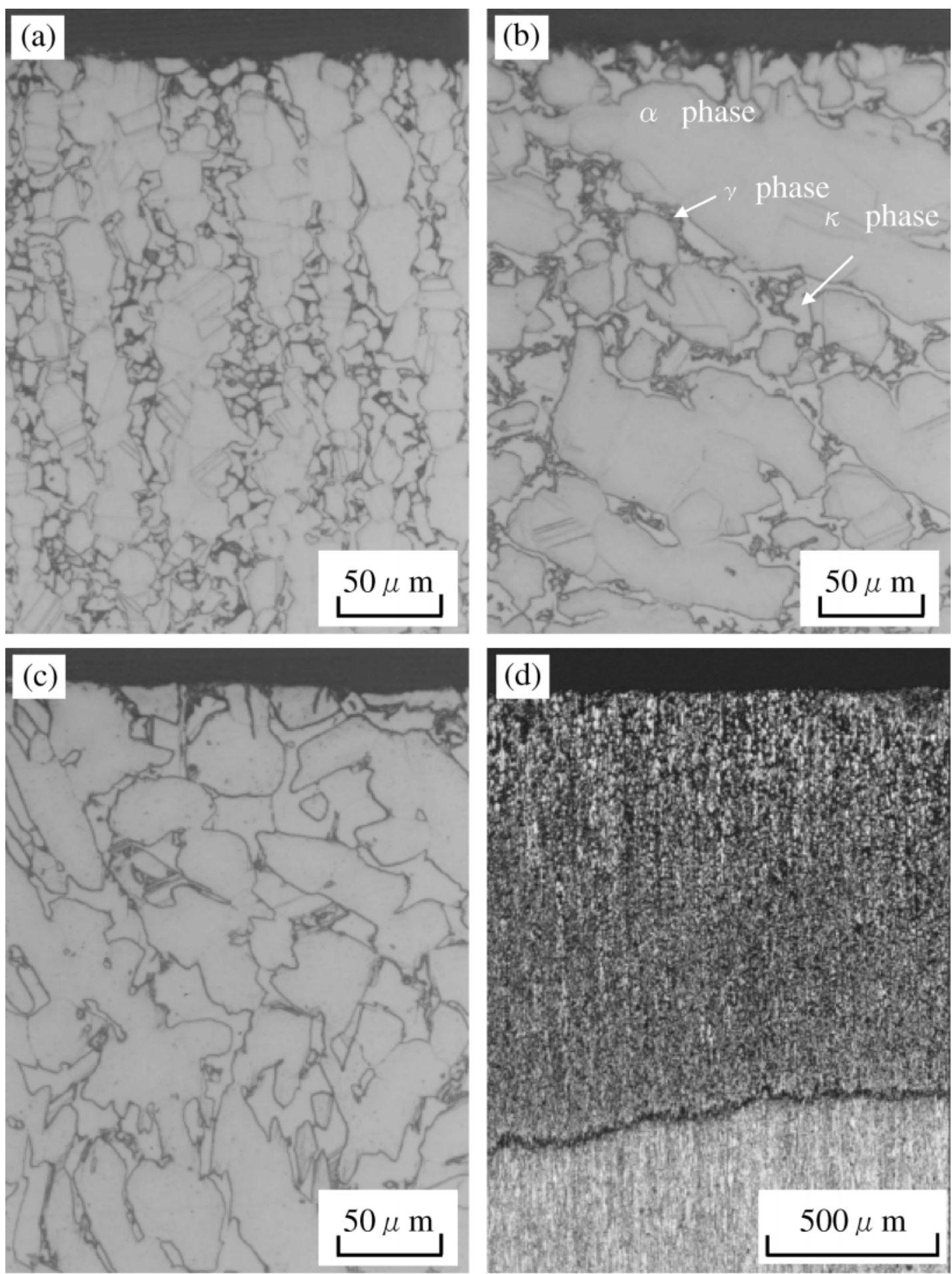

Fig. 1 Microstructures of cross-section of specimens after ISO 6509 dezincification corrosion test.

(a) $75.5 \mathrm{Cu}-3 \mathrm{Si}-0.1 \mathrm{P}-\mathrm{Zn}$ alloy bar, (b) $75.5 \mathrm{Cu}-3 \mathrm{Si}-0.1 \mathrm{P}-\mathrm{Zn}$ alloy forging, (c) $75.5 \mathrm{Cu}-3 \mathrm{Si}-0.1 \mathrm{P}-\mathrm{Zn}$ alloy casting, (d) $\mathrm{C} 3604 \mathrm{bar}$.

起こらなかったものと思われる．これらのことから実用合金 で安定して得られる金属組織は, $873 \mathrm{~K}$ の平衡状態図で示さ れる相構成に最も近いように思われる。

\section{$3.3 \quad$ EPMA による $\alpha$ 相， $\gamma$ 相および $\kappa$ 相の定量分析}

Fig. 4 に本合金の棒材断面の二次電子像を示す. EPMA を用いて， $\alpha$ 相， $\kappa$ 相抢よび $\gamma$ 相の定量分析した結果を Table 2 に示す。分析条件は加速電圧 $20 \mathrm{kV}$, 照射電流 $3 \times$ $10^{-8} \mathrm{~A}$ で行い，ZAF で補正した。また $873 \mathrm{~K}$ における平衡
状態図 (Fig. 3(a))に，各相の組成をプロットした。分析結 果から $\mathrm{Si}$ 濃度は $\alpha$ 相, $\kappa$ 相, $\gamma$ 相の順に, Zn 濃度は $\kappa$ 相, $\alpha$ 相, $\gamma$ 相の順に約 1 mass \%の間隔で高くなっている. 873 $\mathrm{K}$ の平衡状態図と比較すると，実用合金の $\mathrm{Si}$ 濃度は $\kappa$ 相， $\gamma$ 相ともに低く, Zn 濃度は $\kappa$ 相では高いが， $\gamma$ 相では低 い。つまり実用本合金を構成する $\alpha$ 相， $\kappa$ 相抢よび $\gamma$ 相の各 相間の組成差は, $873 \mathrm{~K}$ の平衡状態図から予想される各相間 の組成差に比べ小さい. $\mathrm{Zn}$ 濃度がいずれの相も一般黄銅材 に比べ 15 mass\%以上低く，各相間の $\mathrm{Zn}$ 濃度差が小さいこ 

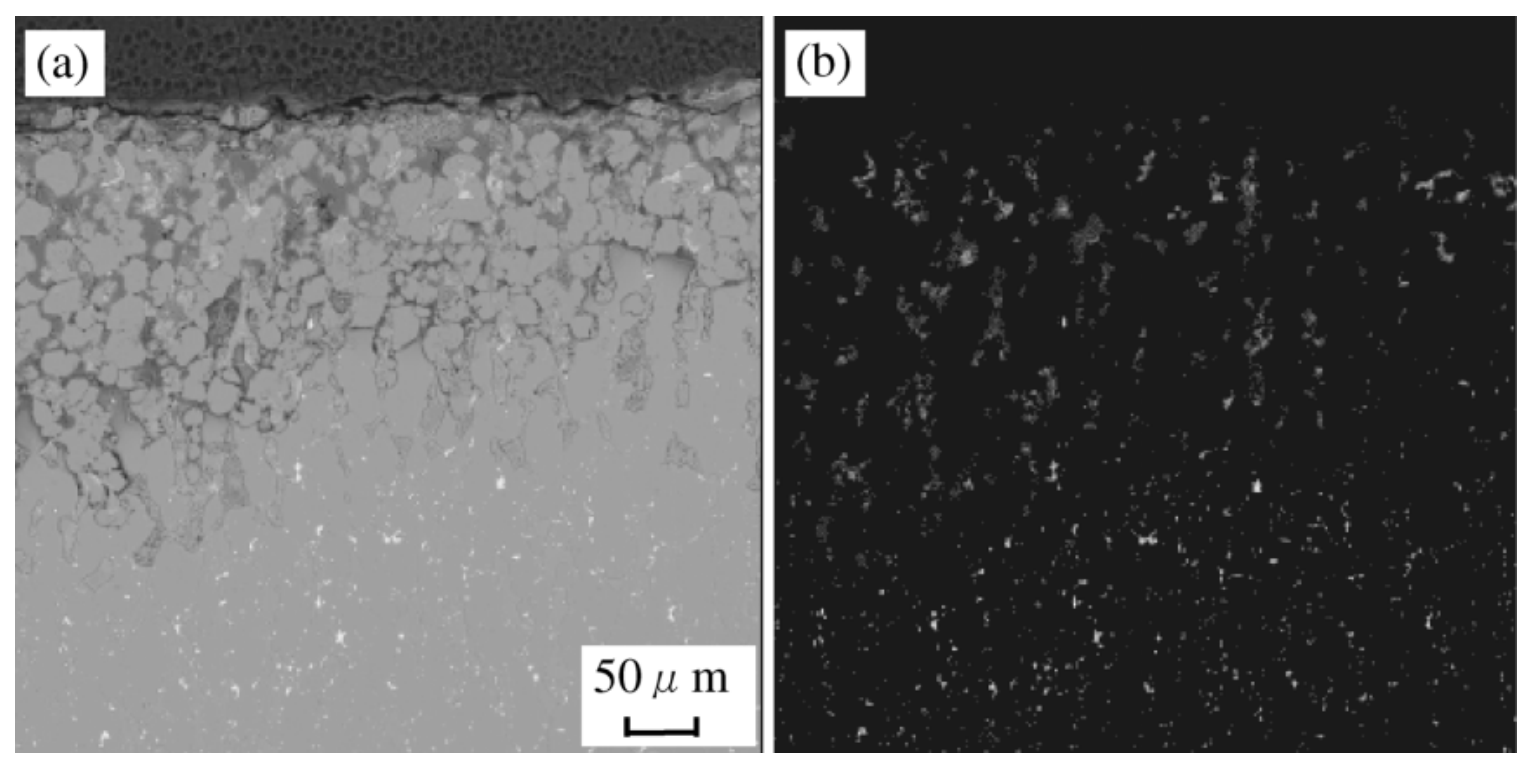

Fig. 2 (a) Composition image and (b) $\mathrm{Pb} \mathrm{X}$-ray image of $\mathrm{C} 3604$ alloy used for about 7 months as plumbing fixtures.
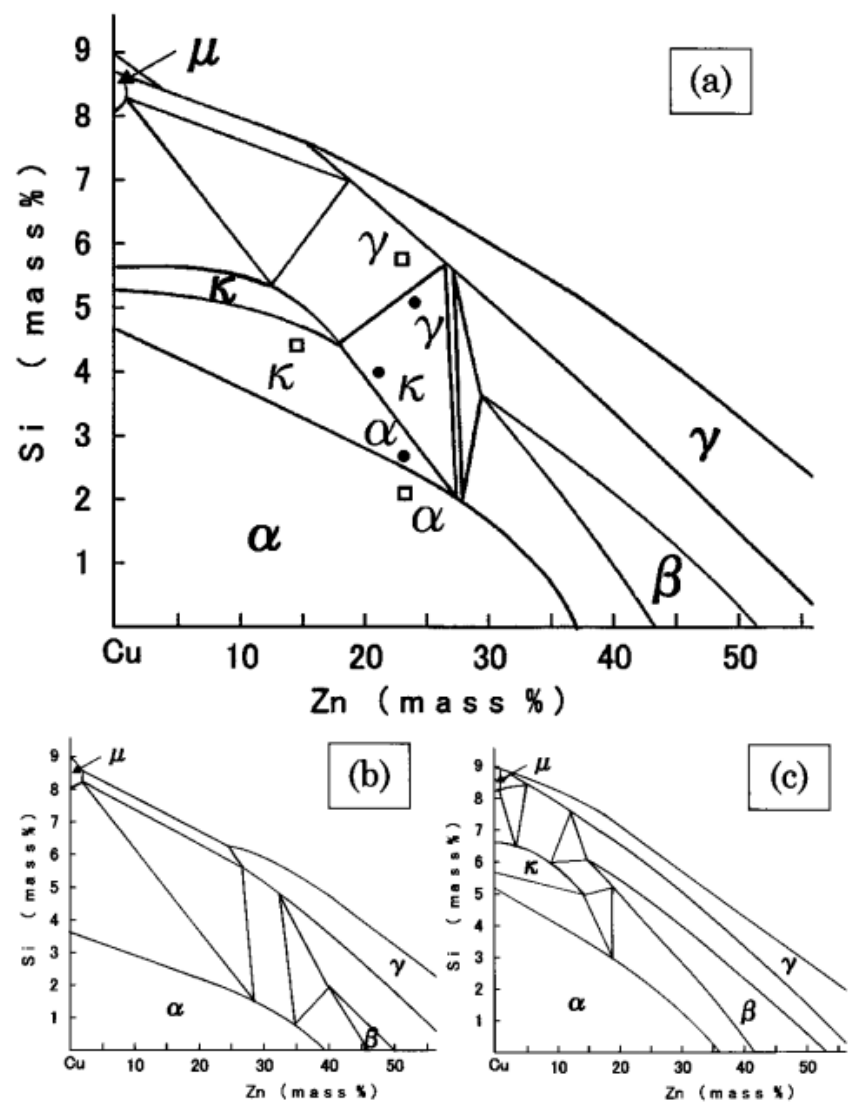

Fig. 3 Equilibrium phase diagrams of horizontal section of $\mathrm{Cu}-\mathrm{Si}-\mathrm{Zn}$ system.

(a) at $873 \mathrm{~K},($ b) at $673 \mathrm{~K}$, (c) at $973 \mathrm{~K}$. O: EPMA quantitative analyses of $\alpha, \kappa$ and $\gamma$ phases in $75.5 \mathrm{Cu}-3 \mathrm{Si}-0.1 \mathrm{P}-\mathrm{Zn}$ alloy, $\square$ : Chemical compositions of single phase specimens in $\mathrm{Cu}-\mathrm{Si}-$ Zn alloy.

と，および $\mathrm{Si}$ も同様に各相間の濃度差が小さいことは，こ れら 3 種類の相から構成される本合金の耐脱亜鉛腐食性に 対して有利に働くことが示唆される.

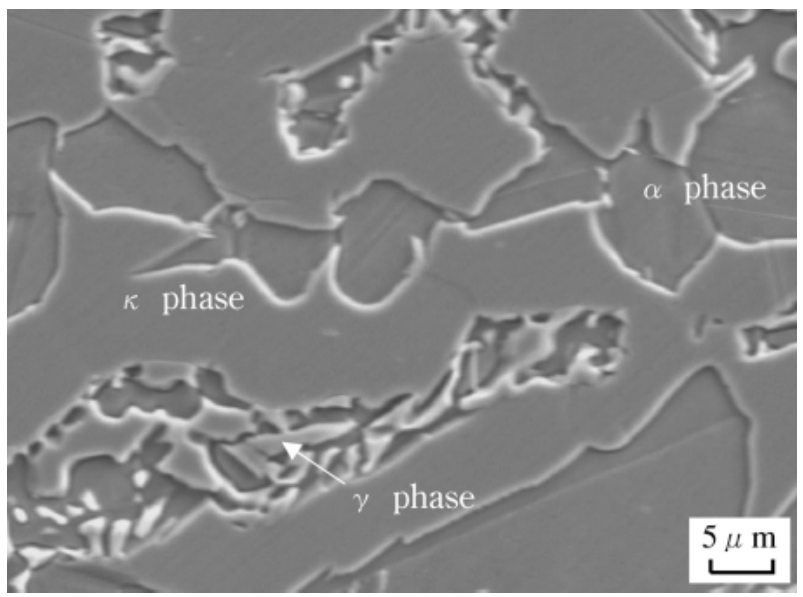

Fig. 4 SEM image of the $75.5 \mathrm{Cu}-3 \mathrm{Si}-0.1 \mathrm{P}-\mathrm{Zn}$ alloy bar.

Table 2 EPMA quantitative analyses of $\alpha$ phase, $\kappa$ phase and $\gamma$ phase in the $75.5 \mathrm{Cu}-3 \mathrm{Si}-0.1 \mathrm{P}-\mathrm{Zn}$ alloy.

\begin{tabular}{cccc} 
& & & $($ mass $\%)$ \\
\hline Phase & $\mathrm{Cu}$ & $\mathrm{Si}$ & $\mathrm{Zn}$ \\
\hline$\alpha$ & 75.35 & 2.80 & 21.85 \\
$\kappa$ & 74.75 & 4.05 & 21.20 \\
$\gamma$ & 71.28 & 5.13 & 23.59 \\
\hline
\end{tabular}

\section{4 単相合金の耐脱亜鉛腐食性}

Table 3 に実用本合金を構成する $\alpha$ 相， $\kappa$ 相， $\gamma$ 相の各単 相合金試料, $\mathrm{Cu}-\mathrm{Si}-\mathrm{Zn}$ 合金の $\beta$ 単相合金試料, $\mathrm{Cu}-\mathrm{Zn}$ 合金 の $\alpha$ 相, $\beta$ 相, $\gamma$ 相の各単相合金試料の組成抢よびそれら単 相試料の ISO 6509 試験結果を示す.

$873 \mathrm{~K}$ で熱処理した各単相合金試料の組成，実用本合金の 各相の組成抢よび $873 \mathrm{~K}$ での平衡状態図との関係をより明 確にするために Fig. 3(a)に単相合金の組成をプロットした. $\kappa$ 単相および $\gamma$ 単相合金は $873 \mathrm{~K}$ の平衡状態図に比べ，低 $\mathrm{Si}$ 側で安定であり若干のずれが認められる。 
Table 3 Chemical compositions of the single-phase specimens in $\mathrm{Cu}-\mathrm{Si}-\mathrm{Zn}$ alloy and $\mathrm{Cu}-\mathrm{Zn}$ alloy, and average dezincification depth of specimens after ISO 6509 test.

\begin{tabular}{|c|c|c|c|c|c|c|}
\hline \multicolumn{2}{|c|}{ Specimens } & \multicolumn{4}{|c|}{ Chemical composition (mass\%) } & \multirow{2}{*}{$\begin{array}{c}\text { Average } \\
\text { dezincification } \\
\text { depth }(\mu \mathrm{m})\end{array}$} \\
\hline Alloy type & Phase & $\mathrm{Cu}$ & $\mathrm{Si}$ & $\mathrm{P}$ & $\mathrm{Zn}$ & \\
\hline \multirow{4}{*}{$\mathrm{Cu}-\mathrm{Si}-\mathrm{Zn}$} & $\alpha$ & 75.79 & 2.17 & 0.07 & 21.97 & 0 \\
\hline & $\beta$ & 63.45 & 1.82 & 0.07 & 34.66 & 170 \\
\hline & $\kappa$ & 80.33 & 4.57 & 0.07 & 15.03 & 0 \\
\hline & $\gamma$ & 71.91 & 5.80 & 0.06 & 22.23 & 15 \\
\hline \multirow{3}{*}{$\mathrm{Cu}-\mathrm{Zn}$} & $\alpha$ & 65.00 & & 0.06 & 34.94 & 0 \\
\hline & $\beta$ & 54.11 & & 0.06 & 45.83 & 225 \\
\hline & $\gamma$ & 36.99 & & 0.07 & 62.94 & 50 \\
\hline
\end{tabular}
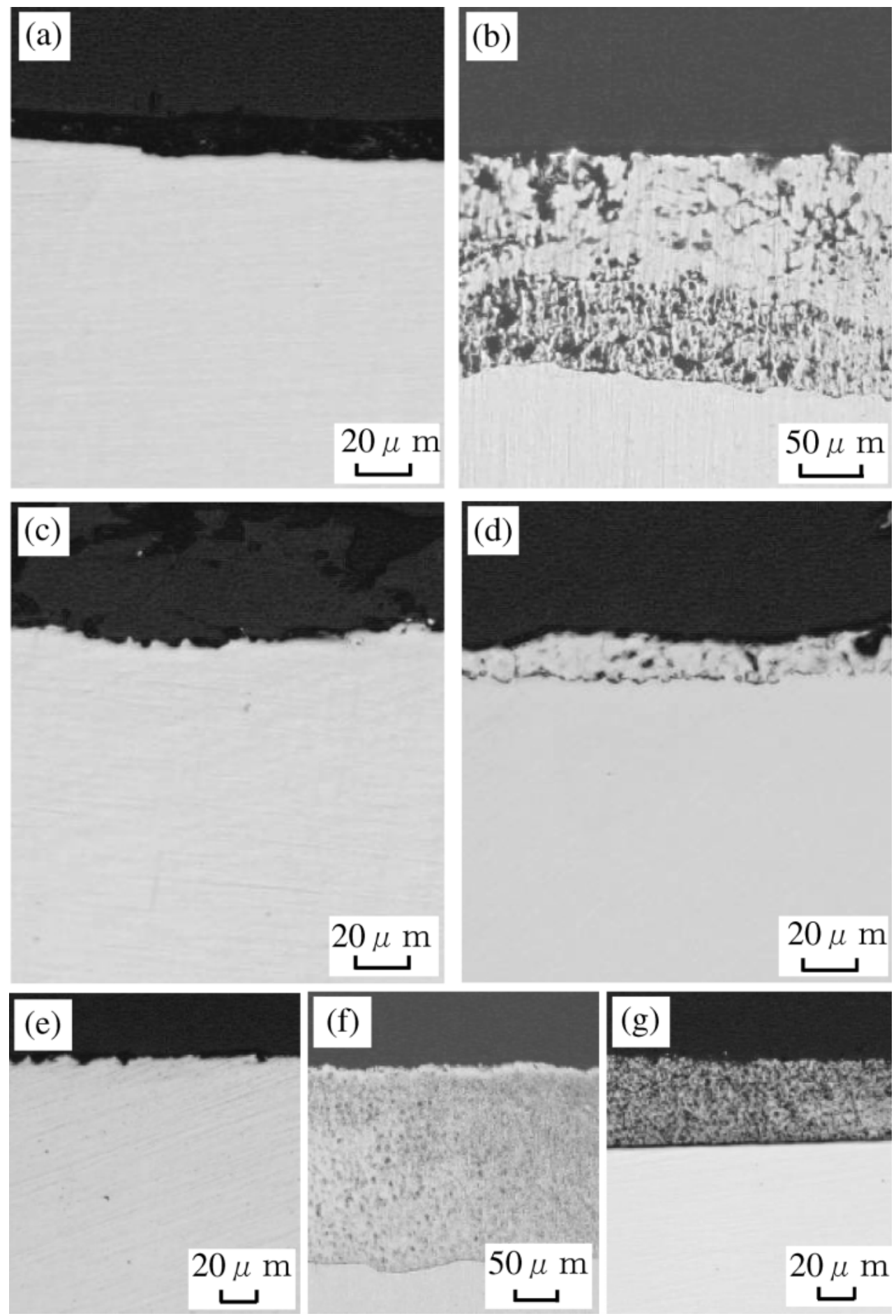

Fig. 5 Optical micrographs of the single-phase specimens after ISO 6509 test.

(a) $\alpha$ phase, (b) $\beta$ phase, (c) $\kappa$ phase, (d) $\gamma$ phase in $\mathrm{Cu}-\mathrm{Si}-\mathrm{Zn}$ alloy, (e) $\alpha$ phase, (f) $\beta$ phase, (g) $\gamma$ phase in $\mathrm{Cu}-\mathrm{Zn}$ alloy.
Fig. 5 に各単相合金の脱亜鉛試験後の断面光学顕微鏡写真 を示す。本合金の $\alpha$ 相と $\kappa$ 相に相当する単相合金試料に は，脱亜鉛腐食が認められず， $\gamma$ 単相合金試料も脱亜鉛腐食 深さが小さい. $\mathrm{Cu}-\mathrm{Si}-\mathrm{Zn}$ 合金の $\beta$ 単相合金試料は $\gamma$ 単相合 金試料より明らかに脱亜鉛腐食が顕著である，一方， $\mathrm{Cu}-\mathrm{Zn}$ 合金において， $\alpha$ 単相合金試料には脱亜鉛腐食が認められな いが， $\beta$ 単相合金試料および $\gamma$ 単相合金試料には，いずれも 脱亜鉛腐食が認められ， $\beta$ 単相合金試料の腐食深さが大き い. 従来から $60 \mathrm{Cu}-40 \mathrm{Zn}$ 合金すなわち $\alpha+\beta$ 黄銅の脱亜鉛 腐食を防止するための研究が行われ， $\mathrm{P}, \mathrm{As}, \mathrm{Sb}$ などの添加 

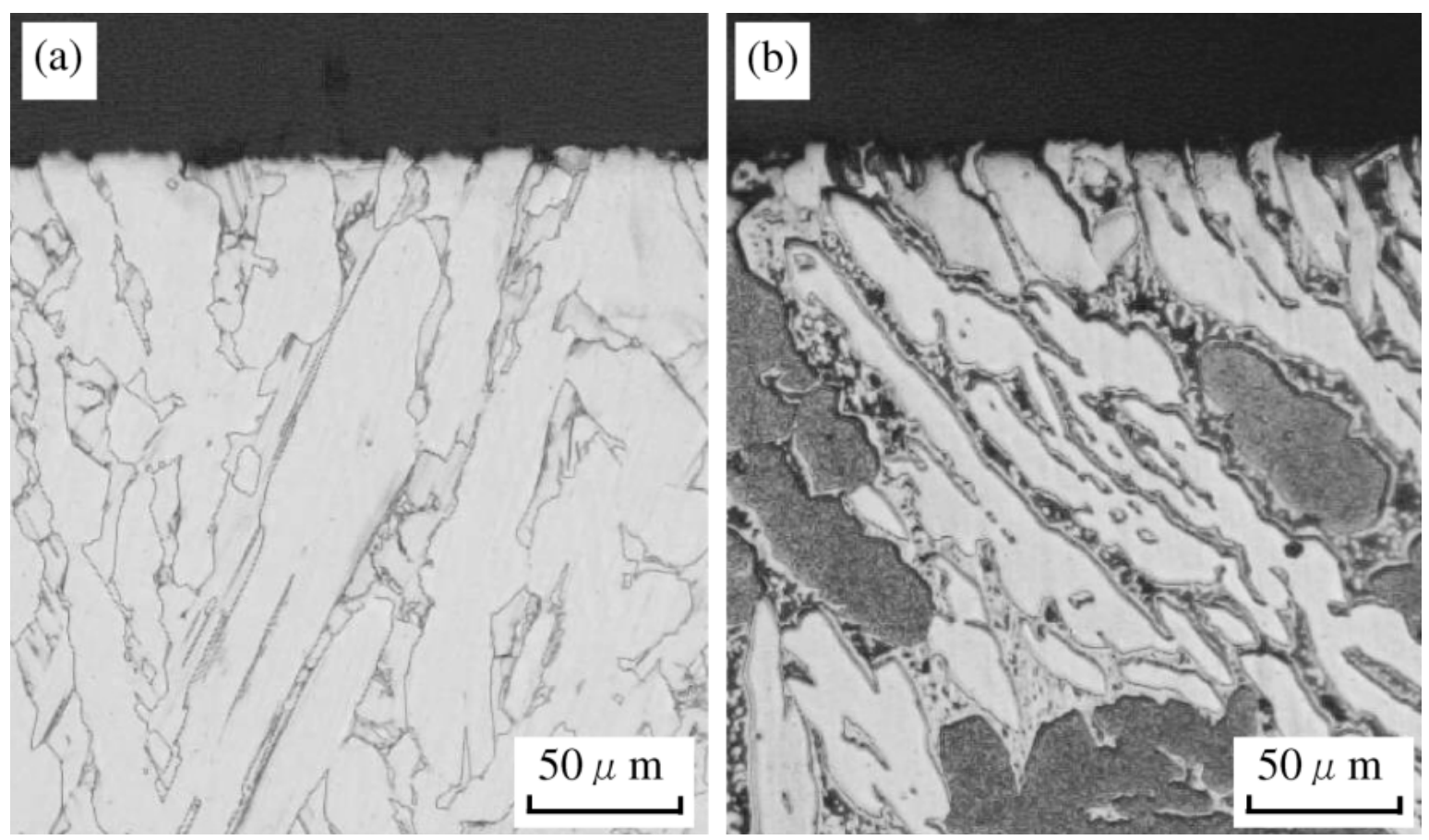

Fig. 6 Optical micrographs of the castings heat-treated at $873 \mathrm{~K}$ for $7.2 \mathrm{ks}$ after ISO 6509 test. (a) $75.5 \mathrm{Cu}-3 \mathrm{Si}-0.07 \mathrm{P}-\mathrm{Zn}$ alloy, (b) $60 \mathrm{Cu}-0.07 \mathrm{P}-\mathrm{Zn}$ alloy.

が $\alpha$ 相の脱亜鉛腐食抑制に非常に有効であるが， $\beta$ 相に対し てはその効果が小さいとされている26-28)。しかし，まだそ の機構は明らかにされていない，工業上，脱亜鉛腐食抑制元 素を少量添加し, Zn 含有量を減少させることによって $\beta$ 相 を低減，分断させ，時には熱処理を施して一層の $\beta$ 相の分 断や $\alpha$ 単相化を図った黄銅 $29-31$ が，脱业鉛腐食対策材とし て広く実用化されている．但し，これらの黄銅は熱間で変形 能に富む $\beta$ 相の占める割合を多くするため熱間加工温度を 上げる必要がある29)。本研究の結果からも $\mathrm{Cu}-\mathrm{Zn}$ 合金に抢 いて $\mathrm{P}$ を添加した $\alpha$ 単相合金試料は脱亜鉛腐食が抑制され るが， $\beta$ 単相合金試料の脱亜鉛腐食が著しく, $\mathrm{P}$ 添加の効果 は少ない，一方 $\beta$ 相より $\mathrm{Zn}$ 濃度の高い $\gamma$ 相は，脱亜鉛腐食 が起こるものの $\beta$ 相に比べるとその度合いが小さい。これ は $\mathrm{P}$ の添加によって $\gamma$ 相の脱亜鉛腐食が抑制されているも のと推察される. 本合金の場合, $\alpha$ 相と $\kappa$ 相は $Z n$ 濃度が低 いことおよび $\mathrm{P}$ による脱亜鉛腐食抑制作用が有効に働き，

優れた耐脱亜鉛腐食性を示したものと考えられる， $\gamma$ 相につ いても $\mathrm{Cu}-\mathrm{Zn}$ 合金の $\gamma$ 相と同様， $\alpha$ 相に比べその効果は少

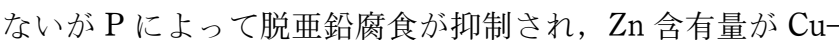
$Z n$ 合金の $\gamma$ 相に比べ約 $1 / 3$ であることから良好な耐脱要鉛 腐食性を示したものと推測される。

$873 \mathrm{~K}$ で熱処理した本合金実験室製作試料の脱亜鉛腐食試 験後の光学顕微鏡写真々暴露面近傍の断面二次電子像, $\mathrm{Si}$, Zn の特性 X 線像を Fig. 6 と Fig. 7 に示す. $60 \mathrm{Cu}-40 \mathrm{Zn}$ 合 金実験室製作試料についても試験後の光学顕微鏡写真を Fig. 6 に併せて示す. 本合金試料は鍛造品などの実用材料と 同様, $\alpha+\kappa+\gamma$ 組織を示し, 最大脱亜鉛腐食深さは $10 \mu \mathrm{m}$ 未満である. EPMA 調査から局所的に暴露表面にある $\gamma$ 相 にZnの選択的な溶解が認められるが， $\alpha$ 相抢よび $\kappa$ 相の脱 $\mathrm{Zn}$ 現象打よび脱 $\mathrm{Si}$ 現象はともに認められない。他方 $60 \mathrm{Cu}-$
$40 Z n$ 合金は， $\alpha$ 相と $\beta$ 相からなり，平均で $500 \mu \mathrm{m} の \beta$ 相 の選択的脱亜鉛腐食が認められ，Pによって脱亜鉛腐食を抑 制できない $\beta$ 相が存在すると耐脱亜鉛腐食性に問題が生じ る. $\alpha$ 相, $\kappa$ 相抢よび $\gamma$ 相の 3 相からなる $75.5 \mathrm{Cu}-3 \mathrm{Si}-$ $0.1 \mathrm{P}-\mathrm{Zn}$ 合金の耐脱亜鉛腐食性は, いずれの相も $\mathrm{Zn}$ 濃度が 24 mass \%以下と低く, P による脱亜鉛腐食抑制効果を持 ち, 各々単独で優れた耐脱亜鉛腐食性を示すことから，優れ ていると考えられる.

\section{4. 結 論}

3 mass $\% \mathrm{Si}$ を添加した $75.5 \mathrm{Cu}-3 \mathrm{Si}-0.1 \mathrm{P}-\mathrm{Zn}$ 鉛フリー快削 性銅合金に扔いて，実用的な金属組織調查と，切削時に有効 に作用する $\kappa$ 相あるいは $\gamma$ 相が用途上必須の耐脱亜鉛腐食 性にどのような影響を与えるかを調查した結果，以下のよう な知見が得られた。

(1) $75.5 \mathrm{Cu}-3 \mathrm{Si}-0.1 \mathrm{P}-\mathrm{Zn}$ 合金の金属組織は，棒材，鍛造 品, 鋳物ともに $\alpha+\kappa+\gamma$ 組織を示し， $\beta$ 相の残留打よび $\mu$ 相の析出は認められず， $873 \mathrm{~K}$ の平衡状態図に示される相構 成に最も近い。

(2) 実用 $75.5 \mathrm{Cu}-3 \mathrm{Si}-0.1 \mathrm{P}-\mathrm{Zn}$ 合金を構成する $\alpha$ 相， $\kappa$ 相 抢よび $\gamma$ 相の各相間の $\mathrm{Zn}$ 抢よび $\mathrm{Si}$ 濃度差は最大で 2.5 mass\%であり，873 K の平衡状態図から推測される濃度差 より小さい。また耐脱亜鉛腐食性に影響を与える Zn 濃度は いずれの相も 24 mass \%以下で，一般黄銅材料より 15 mass \%以上低い。これらのことは耐脱亜鉛腐食性に有利に 働くことを示唆している.

(3) $\quad 0.07$ mass \% P の添加は, $\mathrm{Cu}-\mathrm{Si}-\mathrm{Zn}$ 合金の $\alpha$ 相と $\kappa$ 相の脱西鉛腐食を抑制し， $\gamma$ 相に対しても有效に作用するが， $\beta$ 相に対してはほとんぞ脱刺鉛腐食を抑制出来ないと考えら 

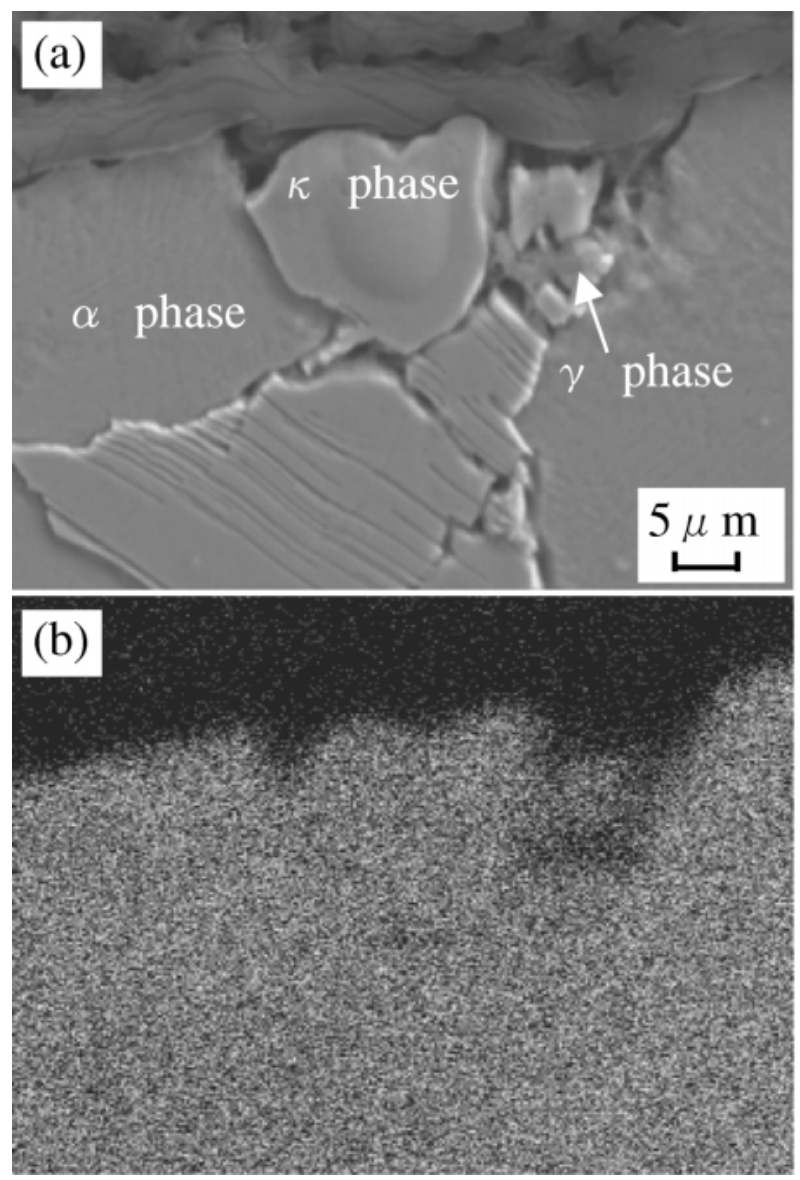

Fig. 7 Cross-sectional SEM image and X-ray images of the $75.5 \mathrm{Cu}-3 \mathrm{Si}-0.07 \mathrm{P}-\mathrm{Zn}$ casting heat-treated at $873 \mathrm{~K}$ for $7.2 \mathrm{ks}$ after ISO 6509 test.

(a) SEM image, (b) Zn X-ray image, (c) Si X-ray image.

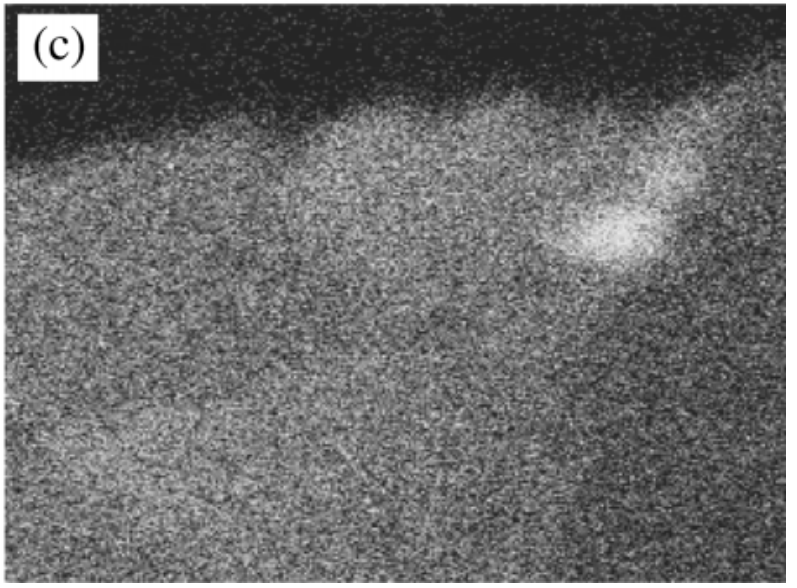

れる。

(4) $\alpha$ 相， $\kappa$ 相および $\gamma$ 相の 3 相からなる実用 $75.5 \mathrm{Cu}-$ $3 \mathrm{Si}-0.1 \mathrm{P}-\mathrm{Zn}$ 合金の耐脱亜鉛腐食性は, いずれの相も $\mathrm{Zn}$ 濃 度が低く, $\mathrm{P}$ による脱亜鉛腐食抑制効果を持ち, 各々単独で 優れた耐脱亜鉛腐食性を示すことから，優れていると考えら れる.

（5）水道関連器具に使用される銅合金の場合，脱亜鉛腐食 に伴う鉛の溶出が問題となる. 鉛含有量を 0.1 mass \%以下 に抑えると同時に優れた耐脱亜鉛腐食性を示す銅合金材料 が，飲用に供する水道関連部材として適当である.

文 献

1) H. Kawana: Journal of Resources and Environment 38 (2002) 229-235.

2) Louice A. Kren: Foundry Management \& Technology (1998) 106-114.

3) HL. Needleman, A. Schell, D. Bellinger, A. Leviton and EN. Allred: New England J. Med. 322 (1990) 83-88.

4) B. R. Allendy: Circuit World 19 (1993) 18-24.

5) Japan Copper and Brass Association, Monthly Report of Japan Brass Makers Association 52(2001) 18-21.

6) Japan Lead Zinc Development Association, Lead and Zinc 234(2001) 44-47.

7) Japan Valve Manufactures' Association, "ECsei-OudouKyusuisen - ni-kansuru - Thousakenkyuhoukokusho", Tokyo (1982) 41-52.

8) T. Sukegawa: Barubu Gihou 35 (1996) 32-41.

9) T. Sukegawa and T. Watanabe: Proc. Int. Symp. (1982) 239255.

10) J. I. Paige and B. S. Covino Jr.: Corrosion 48(1995) 1040-1046.

11) N. Masuko and K. Inoue: Journal of the Japan Copper and Brass Reserch association 23 (1984) 67-78.

12) Standard Specification for Copper-Base Alloy Continuous Castings, ASTM B505-96 (1998).

13) I. Yamauti: New Materials Data Book 18(2002) 455-460.

14) H. Yagyu and O. Hayashi: Nihon-Rinshou Shunkizoukan 43 (1985) 592-594.

15) G. Lagier: Therapie 35(1980) 315-317.

16) T. Matsumoto, M. Huruya, T. Okubo and K. Oishi: Journal of the JRICu $41(2002) 76-80$.

17) K. Oishi, T. Matsumoto and T. Okubo: Materia Japan 39 (2000) 90-92.

18) Robert Heidersbach: Corrosion 24 (1968) 38-44.

19) T. Sukegawa: Heating Piping \& Air Conditioning 30 (1979) 9397.

20) Japan Copper Development Association, "Oudousei-kyuusuisen - no - Taishokusei - no - Hyouka - ni - kansuru - Tyousahoukokusho", Tokyo (1991) 135.

21) K. Nielsen and E. Rislund: Br. Corros. J. 8(1972) 106-116.

22) W. Lynes: Proc. ASTM 41(1941) 869.

23) "Corrosion of metals and alloys - Determination of dezincification resistance of brass.", ISO 6509-1981 (1981).

24) "Health Organization World, Revision of the WHO Guidelines for Drinking Water Quality World Health Organization", WHO Geneva (1993).

25) G. Mima and S. Hasegawa: J. JCBRA 2(1963) 65-77.

26) V. F. Lucey: Br. Corros. J. 1 (1965) 9-53.

27) I. Kawatsu, M. Abe and S. Oyama: J. JCBRA 22 (1983) 231240.

28) H. Sugawara and S. Simodaira: J. Japan Inst. Metals 30 (1966) 775-779.

29) J. E. Bower, P. W. R. Oreland and G. C. Davies: Br. Corros. J. 13 (1978) 177-185.

30) K. Nielsen and E. Rislund: Br. Corros. J. 8(1973) 106-116.

31) J. C. Bitcon: Proc. Int. Symp. (1982) 206-218. 